\title{
EXPLORATION THE IMPACT OF THE CONVERSION PROCESS OF BRI TO BRI SYARIAH ON THE EFFECT OF COMPENSATION ON JOB SATISFACTION AND WORK MOTIVATION AND ITS IMPACT ON EMPLOYEE PERFORMANCE OF BRIREGIONAL OFFICE OF BANDA ACEH
}

\author{
*Irwan, Said Musnadi and T. Roli Ilhamsyah Putra \\ Management Department, Universitas Syiah Kuala, Indonesia \\ http://doi.org/10.35409/IJBMER.2021.3232
}

\begin{abstract}
This study intends to examine the Exploration of the Impact of the BRI to BRI Syariah (BRIS) Conversion Process on the Effect of Compensation on Job Satisfaction and Work Motivation and Its Impact on Employee Performance of BRI Regional Office of Banda Aceh. The population determined in this research was all BRI employees at the Aceh Regional Office totaling 530 employees. To facilitate the process of taking a relevant sample, the Simple Random Sampling technique was used. The sample was taken from 11 branches, one regional office, and one audit office throughout Aceh, 11 people were taken from each office so that the number of the sample used was 13 offices x 11 employees $=143$ people. Data were analyzed using Structural Equation Modeling (SEM) with the help of Amos software. The results of the research found that, directly, the three factors, namely compensation, job satisfaction, and work motivation have a significant impact on employee performance. The impact of compensation on job satisfaction and motivation is also known to be significant, and satisfaction has a significant impact on work motivation. Furthermore, job satisfaction and work motivation have become a significant mediator on the effect of compensation on employee performance. Meanwhile, the BRIS (Organizational Change) conversion moderates significantly the relationship between compensation and job satisfaction, work motivation, and employee performance. This research provides an implementation that organizational change can work well when employee compensation is better or following the previous one so that job satisfaction and work motivation can be maintained or increased and in the end organizational changes can improve employee performance. The novelty of this research lies in the model that was built by testing the moderating effect of the relationships formed to provide a more complete justification for the impact of conversion in the world of Islamic banking. Future researchers should be able to develop this tested research model by adding variables such as employee turnover and organizational support.
\end{abstract}

Keyword: Compensation, Job Satisfaction, Work Motivation, Employee Performance, Conversion.

\section{INTRODUCTION}

Banking is one of the financial institutions that play an important role in the wheels of the country's economy. The resilience and stability of a country's economy can be seen from the 


\section{International Journal of Business Management and Economic Review}

Vol. 4, No. 01; 2021

ISSN: 2581-4664

soundness of the banking system in that country. This is supported by the main function of the bank as an intermediary institution, namely collecting funds from the public (funding) and channeling it back to those in need (lending) and having the aim of supporting the implementation of sustainable national development in the context of creating equitable development to ensure economic growth and growth. Create national economic stability.

One of the banks that has a very central role in supporting the national denomination is the BRI Bank, where BRI Bank is consistent in supporting financing for MSMEs and has the largest network of offices and E-channels in all corners of the archipelago. For the province of Aceh, the role of BRI Bank is very dominant, where the market share for collecting Third Party Funds (DPK) is $20 \%$ and lending is 30\% (BI data for 2019). BRI Bank in Aceh has 1 (one) regional office, 11 (eleven) branch offices, 15 (fifteen) sub-branch offices, and 141 (one hundred fortyone) unit offices.

Aceh is a province with its privileges, namely having special authority in regulating and managing government (autonomy), by applying kaffah sharia principles. The Aceh Regional Government has also announced that the implementation of these sharia principles will be carried out in all aspects of government, economy, and social society as outlined in a regional regulation called Qanun. To apply sharia principles in the economic sector, especially in the financial sector, the Aceh Regional Government issued a regulation as outlined in the Qanun of Islamic Financial Institutions (LKS) no 11 of 2018. One of the important points in the Qanun, namely: Article 6 explains that applies to any person who is Muslim residing in Aceh or a legal entity conducting transactions in Aceh; Every person with a non-Muslim religion, business entity, and / or legal entity conducting financial transactions with the Aceh government and district/city governments: LKS conducting business in Aceh is obliged to run a business with Sharia principles. This Qanun was promulgated on January 4, 2019. Article 65 states that the transition process for all Conventional Financial Institutions into Islamic Financial Institutions is given until January 4, 2022, or 3 (three) years after this qanun is promulgated.

In order to support the process of implementing Qanun 11 of 2018, BRI Bank has taken corporate action, namely by correcting all assets owned by BRI Conventions in Aceh to its business group, namely BRI Syariah (BRIS), and has received full support from the Directors of BRI (parent company). Bank BRIS has done a spin-off so that practically all of its business management is separate from its parent, Bank BRI and Bank BRIS are two companies with different legal entities and both have also been listed on the Indonesia Stock Exchange (listing). The conversion process of conventional BRI Bank to BRIS has started since July 1, 2019. This conversion process includes the transfer of all assets owned by BRI, including productive assets, fixed assets, and all employees.

However, in the conversion process, there are several obstacles, such as: (1) Not all loan and deposit products and their derivatives available at BRI Bank have an equivalent in BRIS, where the banking products at Bank BRI are more numerous and varied; (2) Calculation of the rate or margin for financing using sharia principles is more expensive than conventional banking; (3) Employees currently working at BRI Bank will be assigned to BRIS without leaving their existing work obligations at BRI, especially marketing personnel and business functions. This increases the workload for these employees; (4) Career planning at BRIS is not yet formed and well-systemized like in BRI Bank. Seeing the conditions above, this is a challenge and hard work for all BRI Regional Office Aceh employees at the management level or employees, both 


\section{International Journal of Business Management and Economic Review}

Vol. 4, No. 01; 2021

ISSN: 2581-4664

permanent and contract employees at BRI, starting from Regional Offices, Branch Offices, SubBranch Offices, Unit Offices to Cash Offices. Existing throughout the Aceh Province.

Another factor that has become an obstacle is the significant difference in compensation for BRI and BRIS. This will certainly have an impact on post-conversion employee performance. The conversion of BRI to BRIS did not only provide differences in compensation, motivation, and job satisfaction factors but also in the income system, the relationship between customers, funds, and the basis of sponsorship which also changed. Some of the most dominant indications cause the Organizational Change or conversion process to not run optimally, namely the application of the company's application system that is not in accordance with the standards used by the Conventional BRI. The work skills provided at BRIS have not supported the job properly, as well as the impact of the conversion which requires the recruitment of employees who understand sharia economics.

\section{LITERATURE STUDY}

\section{Employee Performance}

Performance is a condition that shows the level of achievement of an organization related to its vision and mission(Marlina, Majid, \& Madjid, 2018). According to(Mathis \& Jackson, 2019)performance is basically what employees do and don't do. Employee performance is the result of the employee's work during a certain period compared to various possibilities, such as predetermined standards, targets, or criteria.(Robbins \& Judge, 2017)defined employee performance as a result of work both in quality and quantity produced by employees in a certain period in accordance with the given responsibility, so this research uses the following indicators to measure it.

Every organization, including financial organizations especially banks, needs to assess the performance of its employees. Performance appraisals should be used for the promotion of high achieving employees. Performance can be interpreted as the output of a job performed by employees that are assessed in terms of time, cost, accuracy, and ability. According to(Bernardin \& Russell, 2012)employee performance can be measured using 6 (six) indicators, namely: (1) Quality; (2) Quantity; (3) Timeliness; (4) Cost-Effectiveness; (5) Need for Supervision; and (6) Interpersonal Impact. In this research, using these indicators, according to the author's opinion, is more appropriate for BRI employees in order to be able to reveal the phenomena they want to research.

\section{Work motivation}

Motivation is a series of attitudes that influence individuals to achieve specific goals following individual goals. The drive consists of two components, namely: the direction of behavior (work to achieve goals), and the strength of the behavior (how strong is the individual effort at work)(Mahdani, Hafasnuddin, \& Adam, 2017).Motivation can also be interpreted as encouragement that is intended as a natural impetus to satisfy and get the sustainable achievement(Marlina et al., 2018). (Greenberg \& Baron, 2018)expressed employee motivation plays a vital role in the operation and success of an organization. This can be seen in the voluntary efforts made by employees to achieve organizational goals(Robbins \& Judge, 2017). Thus, it can be interpreted that motivation is a good encouragement from within and from 


\section{International Journal of Business Management and Economic Review}

Vol. 4, No. 01; 2021

ISSN: 2581-4664

outside to achieve the desired goal.

According to(Mangkunegara, 2013)someone who has good work motivation can be seen from the following indicators: (1) Responsibility; (2) Job Performance; (3) Opportunities for Advancement; (4) Recognition of Performance; (5) Challenging Work. To measure the work motivation of BRI Bank, this indicator is because according to the author's opinion it is more appropriate to explain BRI's work motivation because it is following the phenomenon to be investigated.

\section{Job satisfaction}

Job satisfaction is a general attitude towards a person's job as the difference between the compensation received by an officer and the amount of compensation that is believed to be received, including job, salary, promotion opportunities, supervision, and co-workers.(Robbins \& Judge, 2017). Meanwhile obeyed(Mahdani et al., 2017)Job satisfaction is the hope of successfully completing a given task following the wishes of the employee himself from any situation. If employees are satisfied with their work, the more they work and think creatively for the betterment of the company. Job satisfaction is a key factor for organizations because it affects performance and productivity, attendance and employee turnover(Onukwube, 2012).

Job satisfaction is a public attitude towards a person's job, which shows the difference between the number of awards received by workers and the amount they believe they should receive. (Sativa, Yunus, \& Majid, 2018). Thus, job satisfaction can be interpreted as feeling happy or unhappy about someone's performance after comparing the input with the output. Indicators that determine job satisfaction(Robbins \& Judge, 2017)namely (1) Mentally challenging work; (2) Supporting working conditions; (3) An appropriate salary or wages; (4) Job promotion; (5) suitability of personality with work; (6) Supporting co-workers.

\section{Compensation}

According to(Mabaso \& Dlamini, 2017)compensation is the payment provided by an employer to its employees for services rendered (eg time, energy, and skills). This includes fixed salaries and variables linked to performance levels. When opportunities arise, workers are likely to turn to higher-paying jobs in either other ministries or the private sector. The way to improve the morale of public sector employees today is to pay attention to compensation. Employees can be attracted, motivated, satisfied, and retained through good and varied monetary rewards (Chinyio, Suresh, \& Salisu, 2018).

(DiPietro, Kline, \& Nierop, 2014)found that employees were satisfied with their job performance while slightly dissatisfied with their salary, and further concluded that compensation is an important motivational factor that can affect job satisfaction. Companies can utilize employee compensation as a management tool to improve performance both in terms of short-term revenue growth and long-term profitability gains. The results further imply that the restaurant company could consider making small but continuous increases in employee compensation to maintain higher performance results(Kim \& Jang, 2020).

(Sinambela, 2016)stated that financial compensation can be divided into direct compensation, such as (1) basic salary and living wage; (2) Bonuses. Then indirect compensation in the form of: (1) Support program; (2) Payment outside working hours; (3) work facilities. In this research, to measure the compensation of BRI employees, it is suitable to use this indicator 


\section{International Journal of Business Management and Economic Review}

Vol. 4, No. 01; 2021

ISSN: 2581-4664

because, in the opinion of the author, financial compensation is more precisely measured considering the impact of the sharia conversion regulations on BRI Bank which BRI employees often complain about is financial compensation.

\section{Organizational Change (Conversion of BRI to BRIS)}

Change always happens, whether on purpose or accidentally. Likewise with organizations that carry out company operations in areas that have different conditions and cultures. Organizations can only survive if they can make changes. Every change leads to organizational effectiveness to seek to improve the organization's ability to adapt to environmental changes and changes in the behavior of organizational members or employees(Robbins \& Judge, 2017).

The theory above illustrates that organizational change will have an impact on the behavior of the organization or employees, in this case, work motivation, job satisfaction, and employee performance. Furthermore, Robbins said that organizational change can be carried out in a structure that includes strategies and systems, technology, physical equipment, and human resources.(Karanja, 2015)argued that change can affect the strategy an organization adopts to carry out its mission, the strategy implementation, the tasks and functions performed by the people in the organization, and the relationships between those people. According to(Vermeulen, 2013)when organizational change is well-intentioned it helps ensure organizational survival. Organizational change is the knowledge that integrates organizational behavior about how people react to the factors that cause pressure to produce results to be more effective.

Organizational change can be managed by setting goal setting. To achieve new organizational changes, agencies must review their planning and implementation strategies and the use of modern systems(Rozanna, Adam, \& Majid, 2019). Some of the differences between Islamic banking principles and conventional ones are located in the contract system, giving rewards, credit/financing targets, interest, and products. Measure organizational change through four indicators according to(Robbins \& Judge, 2017)as follows: (1) work strategies and systems; (2) Technology (communication system); (3) Physical Equipment; (4) Human resources.

\section{Research Paradigm}

Based on the discussion of the problems and research literature, the researcher formulates the research paradigm and hypothesis as follows.

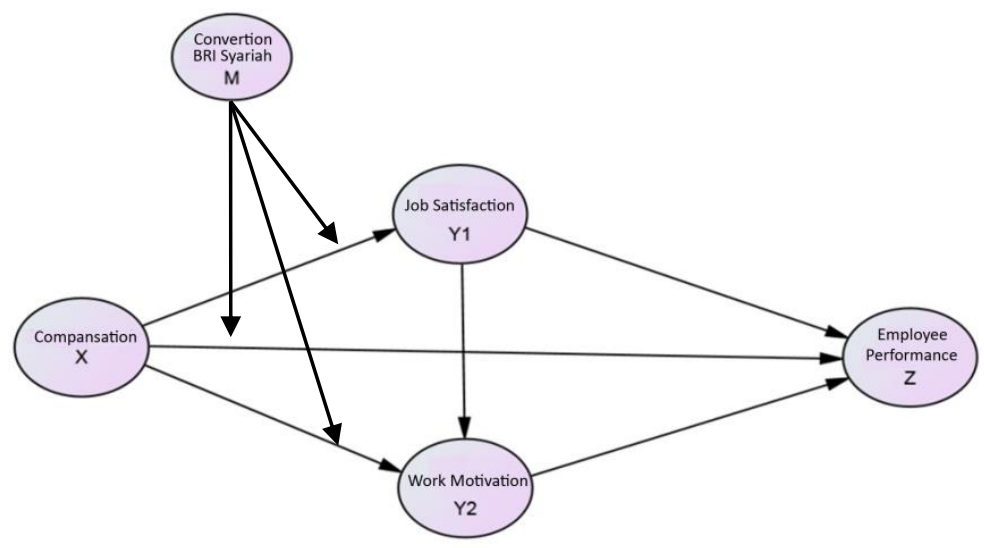

Figure 1. Research Paradigm 


\section{International Journal of Business Management and Economic Review}

Vol. 4, No. 01; 2021

ISSN: 2581-4664

H1 : Employee perceptions of the conversion variable BRIS (Organizational Change), compensation, work motivation, job satisfaction, and employee performance are good

$\mathrm{H} 2$ : Compensation significantly affects employee performance

$\mathrm{H} 3$ : Compensation significantly affects the employee job satisfaction

$\mathrm{H} 4$ : Compensation significantly affects work motivation

H5 : Employee job satisfaction significantly affects employee performance

H6 : Work motivation significantly affects employee performance

H7 : Satisfaction significantly affects work motivation.

H8 : Satisfaction significantly mediates the effect of work compensation on employee performance

H9 : Work motivation significantly mediates the effect of work compensation on employee performance

H10: Job Satisfaction significantly mediates the effect of compensation on work motivation

H11: Motivation significantly mediates the effect of job satisfaction on performance

H12: Conversion of BRIS significantly moderates the effect of Compensation on Employee Job Satisfaction

H13: Conversion of BRIS significantly moderates the effect of Compensation on Employee Performance.

H14: Conversion of BRIS significantly Moderates the effect of compensation on work motivation.

\section{RESEARCH METHOD}

This research uses the object of work compensation as exogenous variables, then job satisfaction and work motivation as mediation, and employee performance of the Banda Aceh Regional Office as endogenous variables. The population determined in this research was all BRI employees at the Aceh Regional Office totaling 530 employees. To facilitate the process of taking relevant samples, the Simple Random Sampling technique was used. The sample was taken from 11 branches, one regional office, and one audit office throughout Aceh. 11 people were taken from each office so that the number of sample used was 13 offices $\times 11$ employees = 143 people.

Data were collected using a questionnaire method, where the list of questions asked provides answers using a Likert scale. The analytical tool used in this research is Structural Equation Modeling (SEM)(Ferdinand, 2014). To test the mediation hypothesis above on the indirect relationship or mediation effect between exogenous and endogenous variables, testing the mediating effect in this research used the model(Baron \& Kenny, 1986). Moderated Regression Analysis (MRA) is used to analyze the effect of the interaction. In the SEM program, several methods can be used to assess the effect of moderation.

Then mathematically the causality relationship between constructs in research can be stated as follows:

Employee Performance $=\gamma 1$ Compensation $+\gamma 12$ Work Motivation $+\gamma 13$ Job Satisfaction $+\zeta 1$

Work Motivation $\quad=\gamma 1$ Compensation $+\gamma 21$ kepuasan kerja $+\zeta 2$

Job Satisfaction $\quad=\gamma 1$ Compensation $+\gamma 22$ Work Motivation $+\zeta 3$ 


\section{International Journal of Business Management and Economic Review}

Vol. 4, No. 01; 2021

ISSN: 2581-4664

Moderated regression analysis is conducted to see whether an uncontrollable variable plays a role in strengthening or weakening the relationship between the influence of one independent variable on the dependent variable(Ferdinand, 2014). One of the methods used in this research is the method developed by(Ping, 1995).

\section{Moderation 1}

Employee Performance $=\gamma 11$ Compensation $+\beta 1$ Conversi BRIS $+\zeta 1$

$=\gamma 11$ Compensation $+\beta 1$ Conversi BRIS + compensation *Conversi

BRIS $+\zeta 1$

Moderation 2

Employee Performance $=\gamma 21$ Work Motivation $+\beta 2$ Conversi BRIS $+\zeta 2$

$=\gamma 21$ Work Motivation $+\beta 2$ Conversi BRIS + Work Motivation *

Moderation 3

Conversion BRIS $+\zeta 2$

Employee Performance $=\gamma 22$ Job Satisfaction $+\beta 3$ Conversion BRIS $+\zeta 2$

$=\gamma 22$ Job Satisfaction $+\beta 3$ Conversion BRIS + Work Motivation * Conversion BRIS $+\zeta 3$

\section{RESULTS AND DISCUSSION}

Descriptive Hypothesis Testing

Descriptive hypothesis testing was carried out using a one-sample test with a cut off value of 3.41 with the following results:

Table1. One-Sample Test

\begin{tabular}{|c|c|c|c|c|c|c|}
\hline & \multicolumn{6}{|c|}{ Test Value $=3.41$} \\
\hline & \multirow[t]{2}{*}{$\mathrm{t}$} & \multirow[t]{2}{*}{ Df } & \multirow{2}{*}{$\begin{array}{l}\text { Sig. } \\
\text { (2-tailed) }\end{array}$} & \multirow{2}{*}{$\begin{array}{l}\text { Mean } \\
\text { Difference }\end{array}$} & \multicolumn{2}{|c|}{$\begin{array}{l}95 \% \text { Confidence Interval of } \\
\text { the Difference }\end{array}$} \\
\hline & & & & & Lower & Upper \\
\hline Compensation & 34.110 & 142 & .000 & 11.898 & 11.21 & 12.59 \\
\hline Job Satisfaction & 40.473 & 142 & .000 & 15.716 & 14.95 & 16.48 \\
\hline Work Motivation & 42.714 & 142 & .000 & 13.716 & 13.08 & 14.35 \\
\hline $\begin{array}{l}\text { Employee } \\
\text { Performance }\end{array}$ & 39.951 & 142 & .000 & 16.674 & 15.85 & 17.50 \\
\hline Conversion BRIS & 36.418 & 142 & .000 & 9.884 & 9.35 & 10.42 \\
\hline
\end{tabular}

Source: SPSS Output Results, 2020 (processed).

From the table above, it can be seen that the level of significance or probability (p) or Sig. (2-tailed) all 0.000 or below the 0.05 figure, so it can be concluded that the variables of compensation, job satisfaction, work motivation, employee performance, and BRIS conversion are still not going well. Thus Hypothesis 1 rejects Ha and accepts H0.

\section{Direct Hypothesis Testing}




\section{International Journal of Business Management and Economic Review}

Vol. 4, No. 01; 2021

ISSN: 2581-4664

The structural model analysis explaining the effect test between variables is presented in the following path diagram:

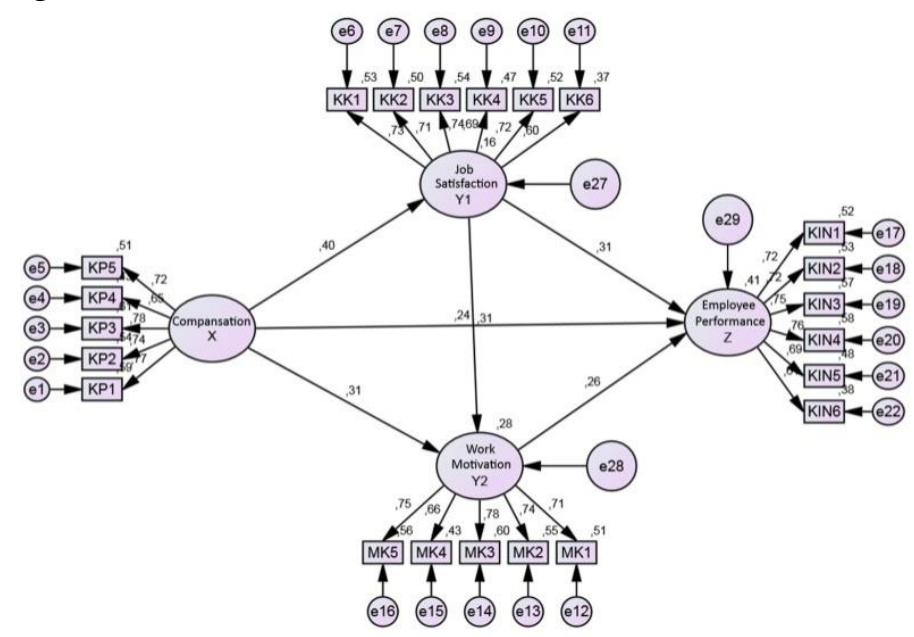

Figure 2. Weight Regression Structural Equational Model

The full model test results for testing the direct effect hypothesis after fulfilling the SEM assumptions are more clearly shown in the following table:

Table 2. Hypothesis Test Results

\begin{tabular}{|l|l|l|l|l|l|l|l|}
\hline \multirow{2}{*}{ Endogenous } & & \multirow{2}{*}{ Exogenous } & \multicolumn{2}{|l|}{ Estimate } & S.E. & C.R. & P \\
\cline { 3 - 6 } & & Standardized & Unstandardized & & \\
\hline $\begin{array}{l}\text { Work } \\
\text { Motivation_Y1 }\end{array}$ & $<---$ & $\begin{array}{l}\text { Compensation } \\
\text { X }\end{array}$ & 0.398 & 0.386 & 0.098 & 3.931 & $* * *$ \\
\hline $\begin{array}{l}\text { Work } \\
\text { Motivation_Y2 }\end{array}$ & $<---$ & $\begin{array}{l}\text { Compensation } \\
\text { X }\end{array}$ & 0.314 & 0.276 & 0.091 & 3.036 & 0.002 \\
\hline $\begin{array}{l}\text { Work } \\
\text { Motivation_Y2 }\end{array}$ & $<---$ & $\begin{array}{l}\text { Job } \\
\text { Satisfaction_Y1 }\end{array}$ & 0.314 & 0.285 & 0.095 & 3.007 & 0.003 \\
\hline $\begin{array}{l}\text { Employee } \\
\text { Performance_Z }\end{array}$ & $<---$ & $\begin{array}{l}\text { Work } \\
\text { Motivation Y2 }\end{array}$ & 0.258 & 0.329 & 0.123 & 2.667 & 0.008 \\
\hline $\begin{array}{l}\text { Employee } \\
\text { Performance_Z }\end{array}$ & $<---$ & $\begin{array}{l}\text { Job Satisfaction } \\
\text { _Y1 }\end{array}$ & 0.314 & 0.304 & 0.109 & 2.793 & 0.005 \\
\hline $\begin{array}{l}\text { Employee } \\
\text { Performance_Z }\end{array}$ & $<---$ & $\begin{array}{l}\text { Compensation } \\
\text { PX }\end{array}$ & 0.237 & 0.217 & 0.102 & 2.129 & 0.033 \\
\hline
\end{tabular}

Source: Primary data processed (processed)

By looking at the test results in table 2, the analysis can be explained as follows:

1. H2: Testing the effect of compensation on employee performance results in a value of $C, R$. value of 2.129 is greater than the cut off value of 1.96. Then the significance value or probability (p) is obtained at 0.033 <of $0.05(5 \%)$. The magnitude of the direct effect of compensation on employee performance obtained from the standard estimate value is 0.237 


\section{International Journal of Business Management and Economic Review}

Vol. 4, No. 01; 2021

ISSN: 2581-4664

or $23.7 \%$. From these results, it is evident that job compensation has a significant effect on employee performance at BRIS. Thus, this hypothesis accepts $\mathrm{Ha}$ and rejects $\mathrm{H} 0$. The results of this research support the research conducted by(Marlina et al., 2018); (Chinyio et al., 2018); (Darma \& Supriyanto, 2017), (Absar, Azim, Balasundaram, \& Akhter, 2010)which stated that there is a significant effect of compensation on employee performance.

2. H3: Testing the Effect of Compensation on Employee Job Satisfaction produces a value of $\mathrm{C}, \mathrm{R}$. worth 3,931 is greater than the cut off value, namely 1.96 . Then the significance value or probability (p) is obtained for the value of *** or $0.000<$ from $0.05(5 \%)$. The magnitude of the direct effect of compensation on job satisfaction obtained from the standard estimate value is 0.398 or $39.8 \%$. From these results, it is evident that job compensation has a significant effect on employee job satisfaction at BRIS. Thus, this hypothesis accepts Ha and rejects $\mathrm{H} 0$. The results of this research support the research conducted by(Chinyio et al., 2018)and(Ahmat, Arendt, \& Russell, 2019)which stated that compensation triggers employee satisfaction in other words compensation has a significant effect on job satisfaction.

3. H4: Testing the Effect of Compensation on Work Motivation produces a value of C.R. value of 3.036 is greater than the cut off value of 1.96. Then the significance value or probability (p) is obtained at $0.002<$ of $0.05(5 \%)$. The magnitude of the direct effect of compensation on work motivation obtained from the standard estimate value is 0.314 or $31.4 \%$. From these results, it is evident that job compensation has a significant effect on work motivation at BRIS. Thus, this hypothesis accepts Ha and rejects H0. The results of this research support the research conducted by(Ahmat et al., 2019), (Chinyio et al., 2018), (DiPietro et al., 2014)(Akhtar, Aziz, Hussain, Ali, \& Salman, 2014)and(Aamir, Jehanzeb, Rasheed, \& Malik, 2012)where their findings stated that compensation triggers higher work motivation, in other words, compensation has a significant effect on work motivation.

4. H5: Testing the Effect of Job Satisfaction on Employee Performance produces a value of C.R. value of 2,793 is greater than the cut off value of 1.96. Then the significance value or probability $(\mathrm{p})$ is obtained at $0.005<$ from $0.05(5 \%)$. The magnitude of the direct effect of job satisfaction on employee performance obtained from the standard estimate value is 0.314 or $31.4 \%$. From these results, it is evident that job satisfaction has a significant effect on employee performance at BRIS. Thus, this hypothesis accepts $\mathrm{Ha}$ and rejects H0. The results of this research support the research being carried out(Adam \& Kamase, 2019), (Chinyio et al., 2018), (Sativa et al., 2018), (Mahdani et al., 2017), and(Onukwube, 2012)that found satisfaction is the trigger for high employee performance

5. H6: Testing the Effect of Work Motivation on Employee Performance resulted in a C.R value of 2.667, greater than the cut off value of 1.96. Then the significance value or probability (p) is obtained at $0.008<$ from $0.05(5 \%)$. The magnitude of the direct effect of work motivation on employee performance obtained from the standard estimate value is 0.258 or $25.8 \%$. From these results, it is evident that work motivation has a significant effect on employee performance at BRIS. Thus, this hypothesis accepts Ha and rejects H0. The results of this research support the research conducted by(Anita, Aziz, \& Yunus, 2019), (Adam \& Kamase, 2019), (Sativa et al., 2018); (Marlina et al., 2018): (Chinyio et al., 2018); (Mahdani et al., 2017)and(Omolo, 2015)where the results of their research concluded that motivation both within and from an employee's self can affect employee performance. 


\section{International Journal of Business Management and Economic Review}

Vol. 4, No. 01; 2021

ISSN: 2581-4664

6. H7: Testing the Effect of Job Satisfaction on Work Motivation produces a C.R value of 3.003 , which is greater than the cut off value of 1.96. Then the significance value or probability (p) is obtained at $0.003<$ of $0.05(5 \%)$. The magnitude of the direct effect of job satisfaction on work motivation obtained from the standard estimate value is 0.314 or $31.4 \%$. From these results, it is evident that job satisfaction has a significant effect on work motivation at BRIS. Thus, this hypothesis accepts $\mathrm{Ha}$ and rejects $\mathrm{H} 0$. The results of this research support the research conducted by(Sativa et al., 2018)and(Akhtar et al., 2014)which states that satisfaction is a trigger to increase work motivation. When employees are satisfied, it will increase their motivation to work. These results reject different research conducted by(Mahdani et al., 2017)which stated that motivation does not affect job satisfaction.

\section{Indirect Hypothesis Testing (Mediation)}

The results of testing the indirect hypothesis (mediation) are described below:

1. H8: The results of indirect hypothesis testing (mediation) as well as the Mediating Job Satisfaction test the effect of Compensation on Employee Performance. To find out the significant effect of mediating job satisfaction on the compensation relationship on employee performance in this research using the Sobel test assistance using the unstandardized estimate value as can be seen in the following figure, it is explained below:

2.

\begin{tabular}{|c|c|c|c|c|}
\hline Input: & & Test statistic: & Std. Error: & p-value: \\
\hline a 0.386 & Sobel test: & 2.27615056 & 0.05155371 & 0.022837 \\
\hline$b \longdiv { 0 . 3 0 4 }$ & Aroian test: & 2.22880926 & 0.05264874 & 0.0258266 \\
\hline$s_{3} 0.098$ & Goodman test: & 2.32664264 & 0.0504349 & 0.01998429 \\
\hline$s_{b} 0.109$ & Reset all & & Calculate & \\
\hline
\end{tabular}

Figure 3. Sobel Test Result of the Hypothesis 8

The Sobel test shows that the indirect effect of compensation on employee performance through job satisfaction using an unstandardized estimate value is significant because it has a p-value (probability value) of 0.02 which is smaller than 0.05 . Based on the results of significance testing for path $\mathrm{C}^{\prime}\left(\mathrm{A}, \mathrm{B}, \mathrm{C}\right.$, and $\left.\mathrm{C}^{\prime}\right)$ can be seen in the following.

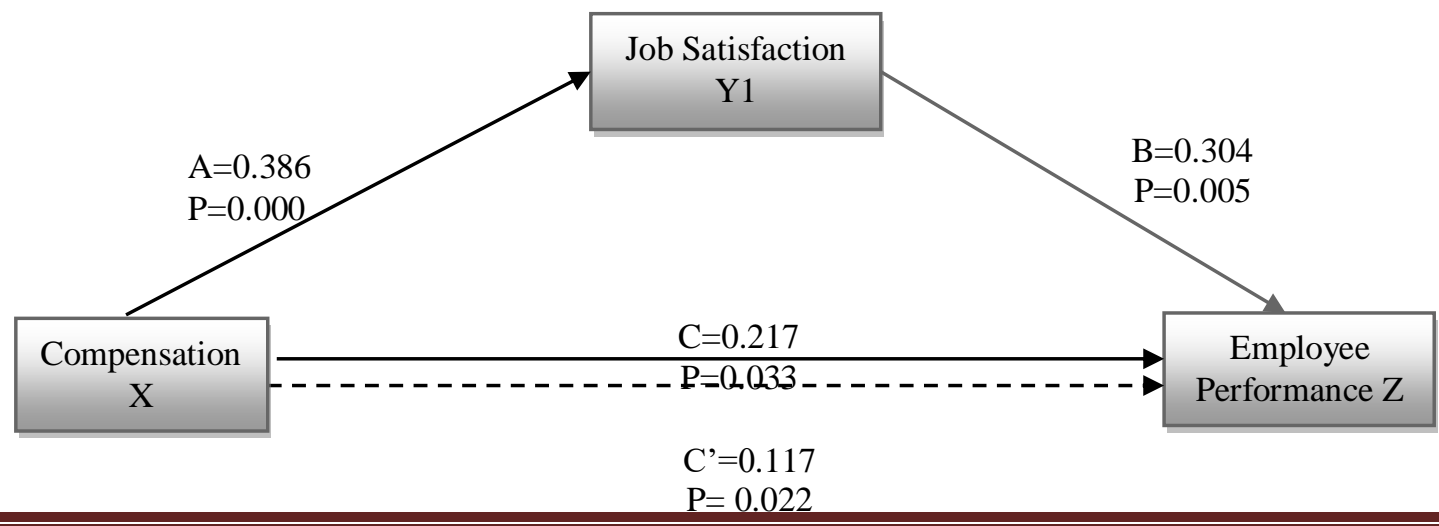




\section{International Journal of Business Management and Economic Review}

Vol. 4, No. 01; 2021

Figure 4.Structural Path of Hypothesis 8

The picture above can be explained that the magnitude of the effect of compensation on employee performance through job satisfaction is $0.117(0.386 \times 0.304=0.117)$ or $11.7 \%$. Thus, it can be stated that satisfaction mediates partially and significantly in the relationship between compensation and employee performance, or in other words, this hypothesis accepts $\mathrm{Ha}$ and rejects $\mathrm{H} 0$. The results of this research support previous research conducted by(Darma \& Supriyanto, 2017)which stated that employee satisfaction can mediate the effect of compensation on employee performance.

3. H9: Work Motivation testing Mediates the effect of Work Compensation on Employee Performance as shown in the following figure.

4.

\begin{tabular}{|c|c|c|c|c|c|}
\hline & Input: & & Test statistic: & Std. Error: & p-value: \\
\hline$a$ & 0.276 & Sobel test: & 2.006107 & 0.04526379 & 0.04484483 \\
\hline$b$ & 0.329 & Aroian test: & 1.94744793 & 0.04662718 & 0.05148106 \\
\hline$s_{a}$ & 0.091 & Goodman test: & 2.07040743 & 0.04385803 & 0.03841421 \\
\hline & 0.123 & Reset all & \multicolumn{3}{|c|}{ Calculate } \\
\hline
\end{tabular}

Figure 5. Test Result of the Hypothesis 9

The Sobel test shows the indirect effect of compensation on employee performance through work motivation using an unstandardized estimate value which is significant because it has a p-value (probability value) of 0.04 which is smaller than 0.05 . Based on the results of significance testing for path $\mathrm{C}^{\prime}\left(\mathrm{A}, \mathrm{B}, \mathrm{C}\right.$, and $\left.\mathrm{C}^{\prime}\right)$ can be seen in the following.

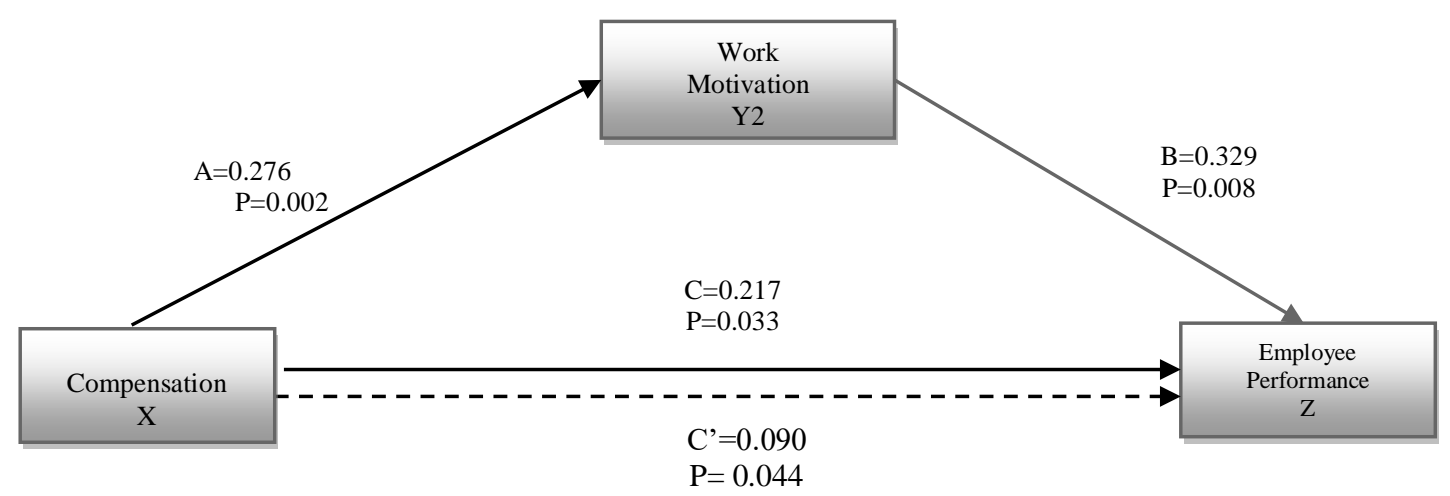




\section{International Journal of Business Management and Economic Review}

Vol. 4, No. 01; 2021

ISSN: 2581-4664

Figure 6. Structural Path of Hypothesis 9

The picture above can be explained that the magnitude of the effect of compensation on employee performance through work motivation is $0.090(0.276 \times 0.329=0.090)$ or $0.90 \%$. Thus, it can be stated that work motivation partially and significantly mediates the relationship between compensation and employee performance, or in other words, this hypothesis accepts $\mathrm{Ha}$ and rejects $\mathrm{H} 0$. The results of this research support previous research conducted by(Chinyio et al., 2018)that found motivation becomes a link between compensation for employee satisfaction and performance.

5. H10: Satisfaction Testing Mediates the effect of compensation on work motivation as shown in the following figure:

\begin{tabular}{|c|c|c|c|c|}
\hline Input: & & Test statistic: & Std, Error: & $p$-value: \\
\hline a 0.386 & Sobel test: & 2.38657899 & 0.04609527 & 0.01700595 \\
\hline$b 0.285$ & Aroian test: & 2.33934143 & 0.04702606 & 0.01931777 \\
\hline$s_{3} 0.098$ & Goodman test: & 2.43679876 & 0.0451453 & 0.01481792 \\
\hline$s_{b} 0.095$ & Reset all & & Calculate & \\
\hline
\end{tabular}

Figure 7. Sobel Test Result of the Hypothesis 10

The Sobel test shows the indirect effect of compensation on work motivation through job satisfaction using an unstandardized estimate value which is significant because it has a p-value (probability value) of 0.01 which is smaller than 0.05 . Based on the results of significance testing for path $\mathrm{C}^{\prime}\left(\mathrm{A}, \mathrm{B}, \mathrm{C}\right.$, and $\left.\mathrm{C}^{\prime}\right)$ can be seen in the following.

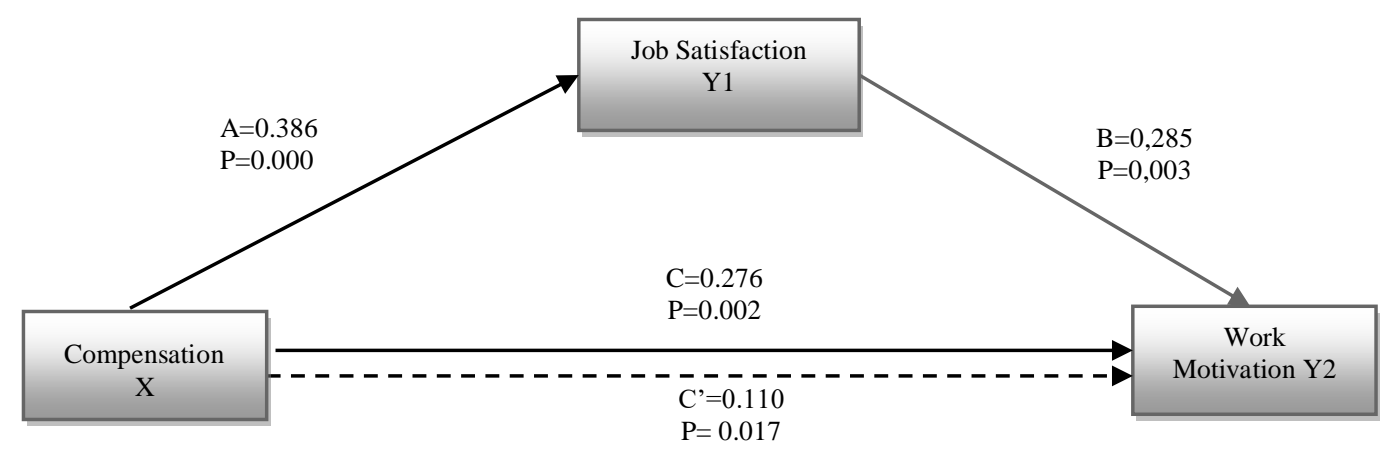

Figure 8. Structural Path of Hypothesis 10

The magnitude of the effect of compensation on work motivation through job satisfaction is $0.110(0.386 \times 0.285=0.110)$ or $11 \%$. Thus, it can be stated that job satisfaction partially and significantly mediates the relationship between compensation and work motivation, or in other words, this hypothesis accepts $\mathrm{Ha}$ and rejects H0. The results of 


\section{International Journal of Business Management and Economic Review}

Vol. 4, No. 01; 2021

ISSN: 2581-4664

this research support previous research conducted by(Chinyio et al., 2018)and(DiPietro et al., 2014)that revealed satisfaction becomes a link between compensation to employee performance.

6. H11: Motivation Testing Mediates the effect of Job Satisfaction on Employee Performance as shown in the following figure:

\begin{tabular}{|c|c|c|c|c|}
\hline Input: & & Test statistic: & Std. Error: & p-value: \\
\hline a 0.286 & Sobel test: & 1.99957252 & 0.04705706 & 0.04554644 \\
\hline b 0.329 & Aroian test: & 1.94063699 & 0.04848614 & 0.05230232 \\
\hline$s_{3} 0.095$ & Goodman test: & 2.06422573 & 0.04558319 & 0.03899632 \\
\hline \begin{tabular}{l|l}
$s_{b}$ & 0.123
\end{tabular} & Reset all & \multicolumn{3}{|c|}{ Calculate } \\
\hline
\end{tabular}

Figure 9. Sobel Test Result of the Hypothesis 11

The Sobel test shows the indirect effect of job satisfaction on employee performance through work motivation using an unstandardized estimate value which is significant because it has a p-value (probability value) of 0.04 which is smaller than 0.05 . Based on the results of significance testing for path $\mathrm{C}^{\prime}\left(\mathrm{A}, \mathrm{B}, \mathrm{C}\right.$, and $\left.\mathrm{C}^{\prime}\right)$ can be seen in the following.

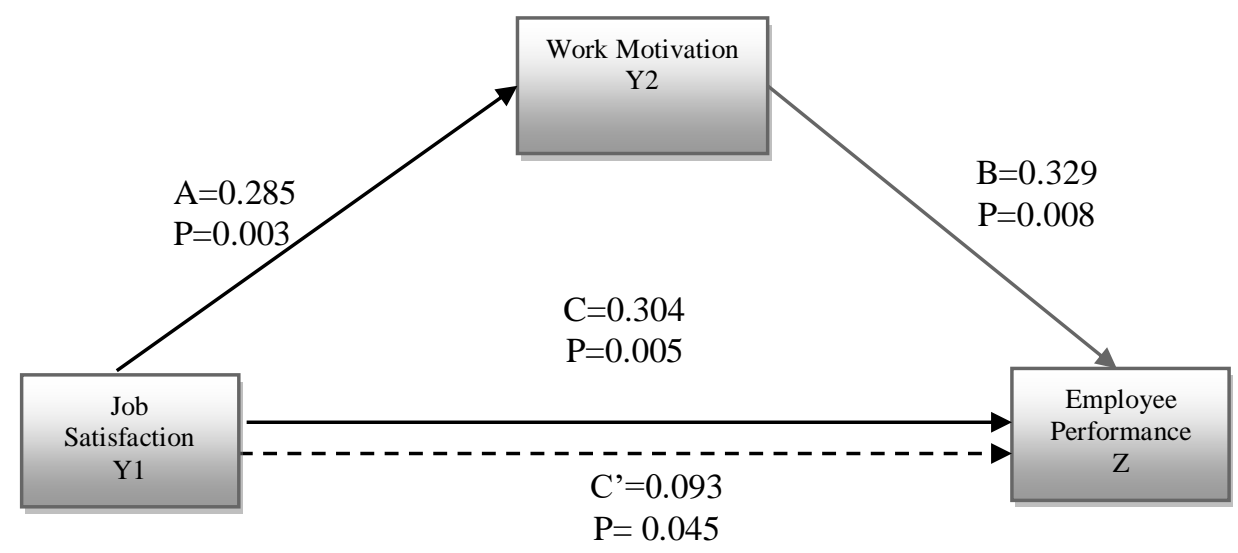

Figure 10. Structural Path of Hypothesis 11

The picture above can be explained that the magnitude of the influence of job satisfaction on employee performance through work motivation is $0.093(0.285 \times 0.329=0.093)$ or $9.3 \%$. Thus it can be stated that work motivation partially and significantly mediates the relationship between job satisfaction and employee performance, or in other words, this hypothesis accepts $\mathrm{Ha}$ and rejects H0. The results of this research support previous research conducted by(Marlina et al., 


\section{International Journal of Business Management and Economic Review}

Vol. 4, No. 01; 2021

ISSN: 2581-4664

2018); (Chinyio et al., 2018); (Sativa et al., 2018); and(Onukwube, 2012)Employees who are satisfied with what they are doing will trigger better performance and work motivation is the main trigger for employee satisfaction and performance.

\section{Testing the Moderation Hypothesis}

There are three moderating relationships from the BRIS conversion that will be tested as follows.

1. H12: BRIS Conversion Test Moderates the effect of Compensation on Employee Job Satisfaction. The results of the moderation test on Hypothesis 12 which tested the impact of the BRIS conversion can strengthen or weaken the compensation relationship on job satisfaction. The test results can be seen in the following figure.

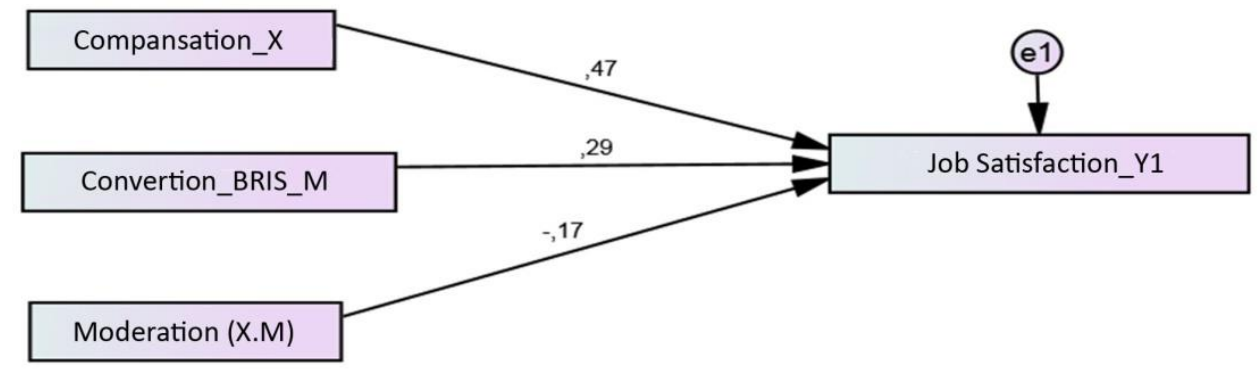

Figure 11. Test Result of Hypothesis 12

The results of the significance test are presented in the SEM output results in the following table.

\section{Table 3. Regression Weights}

\begin{tabular}{|c|c|c|c|c|}
\hline & $\begin{array}{l}\text { of Moderation } \\
\text { Hypothesis } \\
\text { Standardized } \\
\text { Estimate }\end{array}$ & S.E. & C.R. & $\mathrm{P}$ \\
\hline $\begin{array}{l}\text { Job } \\
\text { Satisfaction_Y1 }<--- \text { Compensation_X }\end{array}$ & 0.475 & 0.073 & 6.939 & $* * *$ \\
\hline $\begin{array}{l}\text { Job Satisfaction }<-- \text { Convertion_BRIS_M } \\
\text { _Y1 }\end{array}$ & 0.287 & 0.073 & 4.196 & $* * *$ \\
\hline $\begin{array}{l}\text { Job Satisfaction }<--- \text { Moderation } \\
\text { _Y1 }\end{array}$ & -0.168 & 0.073 & -2.461 & 0.014 \\
\hline
\end{tabular}

Source: AMOS Output Results, 2020 (processed) 


\section{International Journal of Business Management and Economic Review}

Vol. 4, No. 01; 2021

ISSN: 2581-4664

The effect of compensation on job satisfaction is known to be significant at the level of 0.000. Meanwhile, the effect of BRIS conversion on job satisfaction is significant at the 0.000 level. Furthermore, the effect of moderation, namely the result of multiplying the compensation variable with the conversion variable BRIS (X.M), is known to be significant at the level of 0.014 which is smaller than 0.05 . Thus it can be stated that Quasi Moderator. This means that the conversion variable BRIS or Organizational Change can moderate the relationship between compensation and employee job satisfaction but can also be a predictor or exogenous variable. Meanwhile, the value of the Beta or regression estimate standardized is -0.168 or minus is $-16.8 \%$. Thus, it can be stated that organizational change or BRIS conversion can weaken the effect of compensation on job satisfaction, this result is also supported by other facts as the descriptive test results described above show that employees' responses to compensation and job satisfaction are the average answer. employees still disagree or not well.

2. H13: BRIS Conversion Testing can Moderate the effect of Compensation on Employee Performance. The results of the moderation test on Hypothesis 13 which tests the impact of the BRIS conversion can strengthen or weaken the compensation relationship on employee performance. The test results can be seen in the following figure.

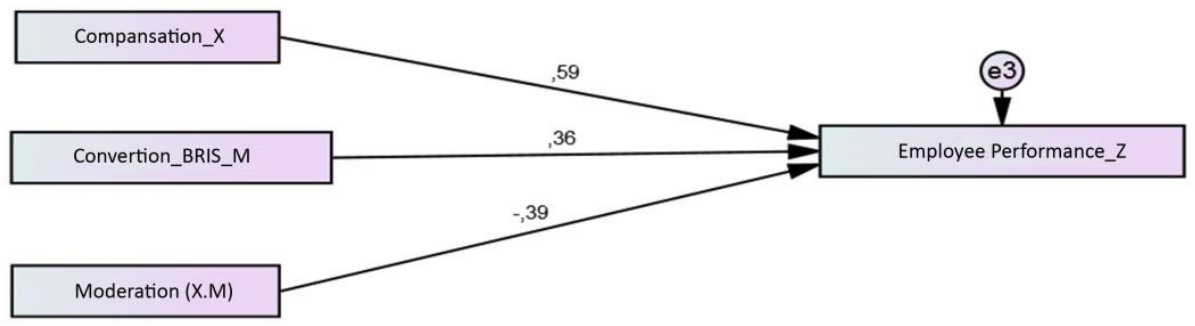

Figure 12. Test Result of Hypothesis 13

To see the significance of the effect of each tested variable, the SEM output results are presented in the following table.

Table 4. Regression Weights of Moderation Hypothesis

\begin{tabular}{|c|c|c|c|c|c|}
\hline & & $\begin{array}{l}\text { Standardized } \\
\text { Estimate }\end{array}$ & S.E. & C.R. & $\mathrm{P}$ \\
\hline $\begin{array}{l}\text { Employee } \\
\text { Performance_ZZ }\end{array}$ & <--- Compensation_X & 0.594 & 0.069 & 11.755 & $* * *$ \\
\hline $\begin{array}{l}\text { Employee } \\
\text { Performance_Z }\end{array}$ & <--- Convertion_BRIS_M & 0.363 & 0.069 & 7.191 & $* * *$ \\
\hline $\begin{array}{l}\text { Employee } \\
\text { Performance_Z }\end{array}$ & <--- Moderation & -0.391 & 0.069 & -7.743 & $* * *$ \\
\hline
\end{tabular}

Source: AMOS Output Results, 2020 (processed) 


\section{International Journal of Business Management and Economic Review}

Vol. 4, No. 01; 2021

ISSN: 2581-4664

The effect of compensation on employee performance is known to be significant at the 0.000 level. Meanwhile, the effect of BRIS conversion on employee performance is significant at the 0.000 level. Furthermore, the effect of moderation, namely the result of multiplying the compensation variable with the conversion variable BRIS (X.M), is known to be significant at a level of 0.00 less than 0.05 on employee performance. Thus it can be stated that Quasi Moderator. This means that the conversion variable BRIS or Organizational Change can moderate the relationship between compensation and employee performance but can also be a predictor or exogenous variable. Meanwhile, the value of the Beta or regression estimate standardized is -0.391 or minus is $-39.1 \%$. Thus it can be stated that organizational change or BRIS conversion can weaken the effect of compensation on employee performance, this result is also supported by other facts as the descriptive test results described above show that employee responses to compensation and average employee performance are still not good.

3. H14: BRIS Conversion Testing can moderate the effect of compensation on work motivation. The results of the moderation test on Hypothesis 14 which tested the impact of BRIS conversion can strengthen or weaken the compensation relationship on work motivation. The test results can be seen in the following figure.

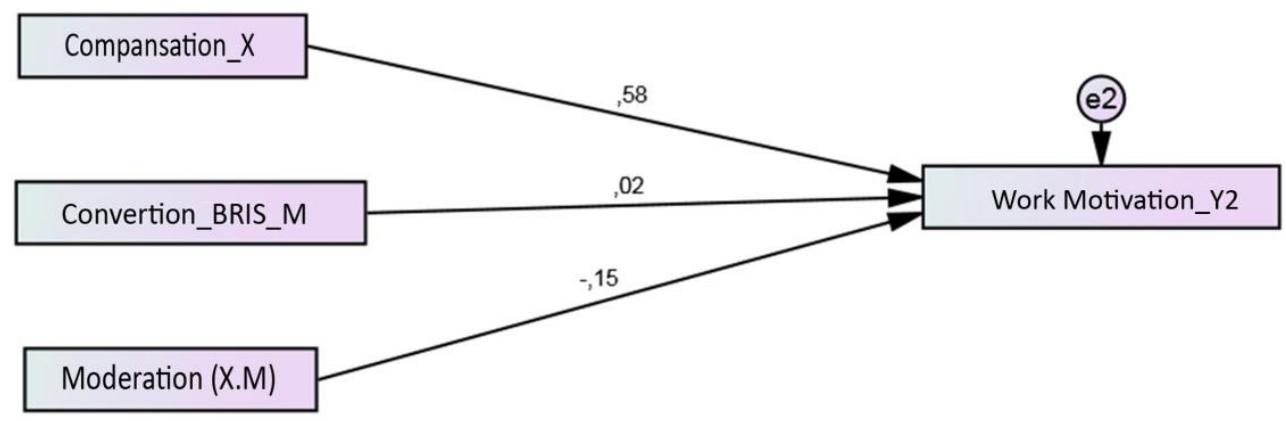

Figure 13.Test Test Result of Hypothesis 14

To see the significance of the effect of each tested variable, the SEM output results are presented in the following table.

Table 5. Regression Weights 


\section{International Journal of Business Management and Economic Review}

Vol. 4, No. 01; 2021

ISSN: 2581-4664

\begin{tabular}{|c|c|c|c|c|c|}
\hline & & $\begin{array}{l}\text { of Moderation } \\
\text { Hypothesis } \\
\text { Standardized } \\
\text { Estimate }\end{array}$ & S.E. & C.R. & $\mathrm{P}$ \\
\hline $\begin{array}{l}\text { Work } \\
\text { Motivation_Y2 }\end{array}$ & <--- Compensation_X & 0.577 & 0.072 & 8.561 & $* * *$ \\
\hline $\begin{array}{l}\text { Work Motivation } \\
\text { _Y2 }\end{array}$ & <--- Convertion_BRIS_M & 0.024 & 0.072 & 0.353 & 0.724 \\
\hline $\begin{array}{l}\text { Work Motivation } \\
\text { _Y2 }\end{array}$ & $<---\quad$ Moderation & -0.149 & 0.072 & -2.207 & 0.027 \\
\hline
\end{tabular}

Source: AMOS Output Results, 2020 (processed)

The effect of compensation on work motivation is known to be significant at the 0.000 level. Meanwhile, the effect of the conversion of BRIS on work motivation is not significant, where the significant value of 0.724 is greater than 0.05 . Furthermore, the effect of moderation, namely the result of multiplying the compensation variable with the conversion variable BRIS (X.M), is known to be significant at the level of 0.027 less than 0.05 on work motivation. Thus it can be stated that Pure Moderator (Pure Moderator). This means that the conversion variable BRIS or Organizational Change moderates the relationship between compensation and full work motivation. Meanwhile, the value of the Beta or regression estimate standardized is -0.149 or minus is $-14.9 \%$. Thus, it can be stated that organizational change or BRIS conversion can weaken the effect of compensation on work motivation, this result is also supported by other facts as the descriptive test results described above show that employees' responses to compensation and work motivation are average. still not good.

\section{CONCLUSION}

Research results on employees of the BRI Regional Office of Banda Aceh found that, directly, the three factors, namely compensation for job satisfaction and work motivation, have a significant impact on employee performance. Compensation for job satisfaction and motivation is also known to be significant, as well as significant satisfaction on work motivation. Furthermore, job decisions and work motivation have become a significant mediator on the effect of compensation on employee performance. The BRIS (Organizational Change) conversion moderates significantly the relationship between compensation and job satisfaction, work motivation, and employee performance. This research provides an implementation that organizational change can work well when employee compensation is better or following the previous one so that job satisfaction and work motivation can be maintained or increased and in the end organizational changes can increase employee performance. The novelty of this research lies in a model built by testing the moderating effect of the formed relationships to provide more robust justification for the impact of conversion in the world of Islamic banking. The interesting thing is that it turns out that conversion can be a trigger for strengthening the impact of compensation on other variables in the model under study. This can be a reference in the 


\section{International Journal of Business Management and Economic Review}

Vol. 4, No. 01; 2021

ISSN: 2581-4664

academic and practical world. Future researchers should be able to develop this tested research model by adding variables such as employee turnover and organizational support.

For the practical world, of course, it can be the basis for formulating a strategy for related research objects, namely BRIS. To improve employee performance at BRIS, one of the factors that must be improved is the provision of compensation following the needs and desires of employees, work motivation, and job satisfaction. Compensation can be increased by providing better salaries, bonuses, benefits, incentives, and work facilities than the previous or the same organization. In the process of organizational change or BRI Syariah Conversion, the strategy and work system at BRIS must be more attractive, the company application system used at BRIS must be more or the same as BRI, the work skills provided at BRIS must be able to support the job well and because Aceh is a region Syariah, BRIS requires the recruitment of employees who understand sharia economics or sharia economics graduates so that the cost of education and training for employees is more efficient.

\section{REFERENCES}

Aamir, A., Jehanzeb, K., Rasheed, A., \& Malik, M. J. (2012). Compensation Methods and Employees' Motivation (With Reference to Employees of National Commercial Bank Riyadh). International Journal of Human Resource Studies, 2(3), 221-230. https://doi.org/10.5296/ijhrs.v2i3.2474

Absar, M. M. N., Azim, M. T., Balasundaram, N., \& Akhter, S. (2010). Impact of Human Resources Practices on Job Satisfaction: Evidence from Manufacturing Firms in Bangladesh. Economic Sciences Series, LXII(2), 32-42. Retrieved from http://hdl.handle.net/123456789/578

Adam, F., \& Kamase, J. (2019). The Effect Competence And Motivation To Satisfaction And Performance. International Journal of Scientific \& Technology Research, 8(3), 132-140.

Ahmat, N. H. C., Arendt, S. W., \& Russell, D. W. (2019). Effects of minimum wage policy implementation: Compensation, work behaviors, and quality of life. International Journal of Hospitality Management, 229-238. https://doi.org/https://doi.org/10.1016/j.ijhm.2019.04.019

Akhtar, N., Aziz, S., Hussain, Z., Ali, S., \& Salman, M. (2014). Factors Affecting Employees Motivation in Banking Sector of Pakistan. Journal of Asian Business Strategy, 4(10), 125133.

Anita, J., Aziz, N., \& Yunus, M. (2019). The Effect Of Placement And Work Load On Work Motivation And Its Impact On Employee Work Performance At Labor And Population Mobility Agency Of Aceh Province, Indonesia. International Journal of Scientific \& Technology Research, 8(4), 225-229.

Baron, R. M., \& Kenny, D. A. (1986). The moderator-mediator variable distinction in social psychological research: Conceptual, strategic, and statistical considerations. Journal of 


\section{International Journal of Business Management and Economic Review}

Vol. 4, No. 01; 2021

ISSN: 2581-4664

Personality and Social Psychology, 51(6), 1173-1182. https://doi.org/10.1037//00223514.51.6.1173

Bernardin, H. J., \& Russell, J. E. A. (2012). Human Resource Management (6th ed.). New York: McGraw-Hill.

Chinyio, E., Suresh, S., \& Salisu, J. B. (2018). The impacts of monetary rewards on public sector employees in construction: A case of Jigawa state in Nigeria. Journal of Engineering, Design and Technology, 16(1), 125-142. https://doi.org/https://doi.org/10.1108/JEDT-122016-0098

Darma, P. S., \& Supriyanto, A. S. (2017). the Effect of Compensation on Satisfaction and Employee Performance. Management and Economics Journal (MEC-J), 1(1), 69-78. https://doi.org/http://dx.doi.org/10.18860/mec-j.v1i1.4524

DiPietro, R. B., Kline, S. F., \& Nierop, T. (2014). Motivation and Satisfaction of Lodging Employees: An Exploratory Study of Aruba. Journal of Human Resources in Hospitality \& Tourism, 13(3), 253-276. https://doi.org/https://doi.org/10.1080/15332845.2014.866466

Ferdinand, A. (2014). Structural Equation Modeling dalam Penelitian Manajemen (5th ed.). Semarang: Badan Penerbit Universitas Diponegoro.

Greenberg, J., \& Baron, R. A. (2018). Behavior in Organizations: Understanding and Managing the Human Side of Work (Ed. 8). New Jersey: Prentice Hall.

Karanja, A. W. (2015). Organizational Change and Employee Performance: A Case on the Postal Corporation of Kenya. European Journal of Business and Management, 7(11), 232-241.

Kim, H. S., \& Jang, S. (Shawn). (2020). The effect of increasing employee compensation on firm performance: Evidence from the restaurant industry. International Journal of Hospitality Management, 8, 1-9. https://doi.org/https://doi.org/10.1016/j.ijhm.2020.102513

Mabaso, C. M., \& Dlamini, B. I. (2017). Impact of Compensation and Benefits on Job Satisfaction. Research Journal of Business Management, 11(2), 80-90. https://doi.org/10.3923/rjbm.2017.80.90

Mahdani, F., Hafasnuddin, \& Adam, M. (2017). Serta Implikasinya Pada Kinerja Karyawan ( Studi Pada Kanwil Pt . Bank Rakyat Indonesia (Persero) Tbk. Banda Aceh. Jurnal Magister Manajemen, 1(1), 1-15.

Mangkunegara, A. P. (2013). Manajemen Sumber Daya Manusia Perusahaan. Bandung: Remaja Rosdakarya.

Marlina, D., Majid, M. S. A., \& Madjid, I. (2018). Mediated Effect of Motivation on the Influences of Emotional Intelligence and Competency on Employees 'Performance Mediated Effect of Motivation on the Influences of Emotional Intelligence and Competency on Employees ’ Performance. (August). https://doi.org/10.9790/487X-2008062735

Mathis, R. L., \& Jackson, J. H. (2019). Human Resource Management: Personnel Human Resource Management (Ed. 15). USA: Harvard Business Review.

Omolo, P. A. (2015). Effect of motivation on employee performance of commercial banks in 


\section{International Journal of Business Management and Economic Review}

Vol. 4, No. 01; 2021

ISSN: 2581-4664

Kenya: A case study of Kenya Commercial Bank in Migori County. International Journal of Human Resource Studies, 57-103. https://doi.org/https://doi.org/10.5296/ijhrs.v5i2.7504

Onukwube, H. N. (2012). Correlates of Job Satisfaction amongst Quantity Surveyors in Consulting Firms in Lagos, Nigeria. Australasian Journal of Construction Economics and Building, 12(2), 43-54. https://doi.org/10.5130/ajceb.v12i2.2460

Ping, R. A. (1995). A Parsimonious Estimating Technique for Interaction and Quadratic Latent Variables. Journal of Marketing Research, 32(3), 336-347. https://doi.org/10.2307/3151985

Robbins, S. P., \& Judge, T. A. (2017). Essential of Organisational Behaviour (14th ed.). New Jersey: Pearson.

Rozanna, N., Adam, M., \& Majid, M. S. A. (2019). Does Job Satisfaction Mediate the Effect of Organizational Change and Organizational Culture on Employee Performance of the Public Works and Spatial Planning Agency? IOSR Journal of Business and Management (IOSRJBM), 21(1), 45-51. https://doi.org/10.9790/487X-2101044551

Sativa, O., Yunus, M., \& Majid, M. S. A. (2018). The Influence of Organizational Culture and Job Satisfaction of Workmotivation and Its Impact on the Performance of Employee. Jurnal Manajemen Inovasi, 9(1), 14-25.

Sinambela, L. P. (2016). Manajemen Sumber Daya Manusia: Membangun Tim Yang Solid Untuk Meningkatkan Kinerja. Jakarta: Bumi Aksara.

Vermeulen, W. J. V. (2013). Self-Governance for Sustainable Global Supply Chains: Can it Deliver the Impacts Needed? Business Strategy and the Environment, 24(2), 73-85. https://doi.org/https://doi.org/10.1002/bse.1804 